\title{
Uji Aktivitas Antioksidan Ekstrak Etanol 70\% Bunga Telang (Clitoria ternatea $L$ ) dari Daerah Sleman dengan Metode DPPH
}

\section{Antioxidant Activity Test of $70 \%$ Ethanol Extract of Telang Flower (Clitoria ternatea L) from Sleman Area with DPPH Method}

\author{
Disa Andriani*, Lusia Murtisiwi \\ Departement of Natural Pharmaceutical Technology and Drug Synthesis, Pharmacy Undergraduate Study \\ Program, SekolahTinggi Ilmu Kesehatan Nasional, Solo-Baki Kwarasan Street, Grogol, Sukoharjo, Central \\ Java, 57552, Indonesia \\ *Email: disa.andrianis anyoto@gmail.com
}

Received: 20 November 2019; Accepted: 23 Juni 2020; Published: 30 Juni 2020

\begin{abstract}
Abstrak
Bunga telang (Clitoria ternatea L.) mengandung senyawa fenolik yang dapat berperan sebagai antioksidan dengan mendonorkan hidrogen sehingga menstabilkan kekurangan elektron pada radikal bebas. Penelitian ini bertujuan untuk mengetahui potensi antioksidan ekstrak etanolbunga telang dengan melihat nilai $\mathrm{IC}_{50}$. Bunga telang diekstraksi dengan metode maserasi menggunakan pelarut etanol $70 \%$. Potensi antioksidan ditetapkan dengan metode DPPH (1,1-diphenyl-2-picrylhydrazyl) dengan pembanding vitamin C yang sudah terbukti memiliki potensi radikal bebas yang sangat poten. Hasil penelitian menunjukkan nilai $\mathrm{IC}_{50}$ ekstrak etanol bunga telang adalah 41,36 $\pm 1,191 \mu \mathrm{g} / \mathrm{mL}$, berdasarkan nilai tersebut ekstrak bunga telang dari daerah Sleman termasuk kategori sangat poten sehingga dapat dikembangkan sebagai salah satu sumber antioksidan dari bahan alam.
\end{abstract}

Kata kunci : Ekstrak bunga telang, antioksidan, DPPH, IC50

Abstract

Telang flower (Clitoria ternatea L.) contains phenolic compounds which can actas antioxidants by donating hydrogen so as to stabilize the lack ofelectrons in free radicals. This study aims to determine the antioxidant potential of telang flower ethanol extract by looking at the $I_{50}$ value. Telang flowers were extracted by maceration method using $70 \%$ ethanol solvent. The potential for antioxidants was determined by the DPPH (1,1-diphenyl-2-picrylhydrazyl) method with a comparison of vitamin $C$ which had been shown to have the potential offree radicals which were very potent. The results showed the IC 50 value oftelang flower ethanol extract was $41.36 \pm 1.191 \mu \mathrm{g} / \mathrm{mL}$, based on that value the telangflower extract from the Sleman area was in the very potent category so that itcould be developed as a source of antioxidants from natural ingredients. Keywords: telang flower extract, antioxidant, $D P P H, I C 50$

\section{PENDAHULUAN}

Dalam beberapa tahun terakhir, sejumlah besar bukti telah berkembang mendukung peran kunci dari radikal bebas dalam banyak reaksi seluler. Radikal bebas dapat mengoksidasi asam nukleat, protein, lipid sehingga menginisiasi terjadinya degenerasi dan kerusakan sel. Tubuh dapat terpapar radikal bebas melalui faktor lingkungan seperti polusi, intensitas sinar UV yang berlebih, suhu, bahan kimia, dan kekurangan gizi. Jika jumlah radikal bebas berlebih, maka dapat terjadi ketidakseimbangan antara molekul radikal bebas dengan antioksidan endogen. Saat jumlah radikal bebas melebihi kapasitas tubuh untuk menetralkannya, maka terbentuk stres oksidatif. Stres oksidatif yang berlangsung lama dapat menyebabkan terjadinya kerusakan sel dan jaringan. Kerusakan sel dan jaringan ini dapat memicu munculnya penyakit-penyakit degenaratif (Susantiningsih, 2015). Berbagai penyakit degeneratif tersebut adalah kardiovaskular, kerusakan retina, katarak, hepatitis, artritis reumatoid, stroke, asma, diabetes melitus, imunodepresi, kanker, hiperoksia, dermatitis, penuaan dini (Phaniendra and Jestadi, 2015) 
Antioksidan merupakan setiap zat yang apabila dalam konsentrasi rendah dibandingkan substrat yang teroksidasi dapat secara signifikan menunda atau mengha mbat oksidasi substrat tersebut. Mekanisme antioksidan digolongkan menjadi 2 yaitu Elektron Transfer (ET) dan Hidrogen Elektron Transfer (HET). Elektron Transfer (ET) berdasarkan reaksi reduksi dan oksidasi dengan mengukur kapasitas antioksidan yang ditandai terjadinya perubahan warna, sedangkan Hidrogen Elektron Transfer (HET) digunakan untuk mengukur kemampuan antioksidan dalam menghambat radikal bebas dengan donor atom hidrogen (Apak, et al., 2013). Peran fisiologis antioksidan adalah untuk mencegah kerusakan komponen seluler yang timbul sebagai konsekuensi dari reaksi kimia yang melibatkan radikal bebas (Werdhasari, 2014).

Bunga Telang tidak hanya dimanfaatkan sebagai tanaman hias tetapi juga sebagai obat tradisional (Purba, 2020). Bunga telang (Clitoria ternatea L.) diketahui mengand ung flavonoid, antosianin, flavonol glikosida, kaempferol glikosida, quersetin glikosida, mirisetin glikosida (Kazuma, et al., 2013), 3O-(2"-O-alfarhamnosil-6"-O-malonyl)-betaglukosda, 3-O-(6"-O-alfa-rhamnosil-6"-Omalonil)-betaglukosida dan 3-O-(2",6"-di-Oalfarhamnosil)-beta-glukosida kaemferol, quersetin dan mirisetin diisolasi dari kelopak bunga. Delfinidin glikosida, 3-O-b-glukosida, 3-O(2"-O-a-rhamnosil)-b-glukosida, 3-O-(2"O-a-rhamnosil-6"-O-malonil)-b-

glukosidadelfinidin, dan delapan antosianin (ternatin $\mathrm{C} 1, \mathrm{C} 2, \mathrm{C} 3, \mathrm{C} 4, \mathrm{C} 5$ dan D3, serta preternatin $\mathrm{A} 3$ dan $\mathrm{C} 4$ ) juga diisolasi dari bunga telang (Kogawa, et al., 2006; Terahara, et al., 1998). Selain itu bunga telang juga mengandung terpenoid, tannin dan steroid (Gupta, 2010). Menurut Duta and Ray (2014), senyawa fenolik berkorelasi positif dengan aktivitas antioksidan, sehingga polifenol kemungkinan merupakan senyawa yang memberikan potensi aktivitas antiradikal dari bunga telang. Berdasarkan hasil penelitian Andriani dan Murtisiwi (2018) terdahulu, didapatkan kadar fenolik total ekstrak etanol bunga telang sebesar 19,43 \pm 1,621 GAE (mg/g sampel). Penelitian Anisa (2019) menunjukkan uji aktivitas antioksidan ekstrak bunga telang dari daerah Bogor dengan menggunakan pelarut etanol $96 \%$ tidak poten sebagai antioksidan. Berdasarkan penelitian Sholekah (2017) menunjukkan bahwa kandungan fitokimia hasil dari metabolit sekunder seperti flavonoid dan beta karoten dari suatu tanaman akan berbeda pada setiap wilayah dipengaruhi oleh faktor lingkungan seperti cahaya, suhu, $\mathrm{pH}$, ketinggian tempat, dan temperatur.

Selain itu, konsentrasi etanol berpengaruh terhadap rendemen, total fenol, total flavono id dan aktivitas penghambat radikal DPPH dengan kandungan tertinggi terdapat pada ekstrak etanol 70\% (Suhendra, et al., 2019). Hal ini mendasari perlu dilakukannya uji aktivitas antioksidan ekstrak etanol bunga telang (Clitoria ternatea L.) dengan pelarut etanol $70 \%$ dan berasal dari sumber lain dengan ketinggian berbeda yaitu dari Kecamatan Kalasan, Kabupaten Sleman, Daerah Istimewa Yogyakarta. Melalui penelitian ini diharapkan dapat meningka tkan pemanfaatan bunga telang dari daerah Sleman, Daerah Istimewa Yogyakarta sebagai sumber antioksidan alami.

\section{METODE PENELITIAN}

Alat

Alat yang digunakan pada penelitian ini meliputi alat-alat gelas yang lazim digunakan di laboratorium; mikropipet; spektrofotometer UV-Vis (UV Mini SHIMADZU).

\section{Bahan}

Bunga telang yang diperoleh dari Kelurahan Purwomartani, Kecamatan Kalasan, Kabupaten Sleman, Daerah Istimewa Yogyakarta; DPPH (Sigma, Chem.Co, ); etanolp.a.(E.Merck); dan vitamin C (Sigma Co.).

\section{Ekstraksi}

Bunga telang (Clitoria ternatea $\mathrm{L}$ ) yang telah dikeringkan sampai kadar airnya kurang dari $10 \%$, dibuat serbuk yang melewati 
ayakan mesh $-20+30$. Ekstraksi simplisia dilakukan dengan metode maserasi berdasarkan Farmakope Herbal Indonesia (Departemen Kesehatan RI, 2008) yang dimodifikasi. Maserasi simplisia bunga telang yang dilakukan berdasarkan Andriani dan Murtisiwi (2018).

Uji aktivitas antioksidan (metode DPPH)

Aktivitas antiradikal dalam ekstrak etanol bunga telang ditentukan dengan metode DPPH sesuai yang dilakukan Widhihastuti (2011).

\section{Pembuatan larutan pereaksi DPPH}

Sebanyak 15,77 mg DPPH ditimbang seksama kemudian dilarutkan dengan etanol p.a sampai tepat $100,0 \mathrm{~mL}$, sehingga diperoleh konsentrasi $0,4 \mathrm{mM}$. Larutan DPPH ini disimpan dalam wadah yang dilapisi alumunium foil di almari es.

Penentuan panjang gelombang maksimum $\left(\lambda_{\text {maks }}\right)$

Sebanyak $0,7 \mathrm{~mL}$ DPPH ditempatkan dalam labu takar 5,0 mL, ditambah etanol p.a sampai tanda, diukur absorbansinya pada panjang gelombang 450-545 $\mathrm{nm}$ terhadap blangko 5,0 mL etanol p.a, diplotkan harga absorbansi maksimum.

\section{Pembuatan larutan stok ekstrak etanol bunga telang}

Sampel ekstrak etanol bunga telang ditimbang 10,00 $\mathrm{mg}$, ditambah pelarut etanol p.a, divorteks sampai homogen, dimasukkan dalam labu takar 10,0 $\mathrm{mL}$, sehingga didapatkan larutan dengan konsentrasi 0,1\%.

\section{Pembuatan larutan stok vitamin $\mathbf{C}$}

Vitamin C ditimbang 10,00 mg, ditambah pelarut, divorteks sampai homogen, dimasukkan ke dalam labu takar 10,0 mL, ditambah pelarut sampai tanda, didapatkan larutan dengan konsentrasi $0,1 \%$.

Penentuan $\mathrm{IC}_{50}$ ekstrak etanol bunga telang

Sejumlah larutan stok ekstrak etanol bunga telang serta vitamin $\mathrm{C}$ dengan lima seri konsentrasi yaitu $10,20,30,40$, dan 50 $\mu \mathrm{g} / \mathrm{mL}$, ditempatkan dalam labu takar 5,0 mL. Sampel selanjutnya ditambah dengan $0,7 \mathrm{~mL}$ DPPH 0,4 $\mathrm{mM}$ dan ditambah etanol hingga tanda. Campuran tersebut divorteks selama 30 detik dan diinkubasi selama 30 menit. Absorbansi sampel diukur terhadap blangko yang terdiri dari sejumlah larutan stok dalam etanol pada $\lambda$ maks. Selain itu, dibandingkan dengan kontrol Vitamin $\mathrm{C}$ dengan berbagai seri konsentrasi yaitu $1,25,2,5,5,10,20$ $\mu \mathrm{g} / \mathrm{mL}$ dan $0,7 \mathrm{~mL}$ DPPH $0,4 \mathrm{mM}$ dalam etanol p.a. hingga tanda. Kemudian dihitung $\%$ aktivitas antiradikal. Pembuatan kurva regresi linier antara konsentrasi melawan \% aktivitas antiradikal sehingga didapatkan persamaan regresi linier untuk menentukan konsentrasi sampel pada aktivitas 50\%. Uji aktivitas antiradikal direplikasi sebanyak tiga kali. Setiap sekali uji, pembuatan stok dan pengenceran sampel juga direplikasi sebanyak tiga kali.

Analisis

Penentuan aktivitas antiradikal dilakukan dengan perhitungan inhibitory concentration (IC50). Nilai $\mathrm{IC}_{50}$ merupakan konsentrasi ekstrak dan vitamin $\mathrm{C}$ yang memberikan \% aktivitas antiradikal sebesar 50\% dibanding kontrol melalui suatu persamaan garis regresi linier antara kadar terhadap \% penangkapan radikal (Widhihastuti, 2011).

$$
\begin{aligned}
& \% \text { aktivitas antiradikal } \\
& =\frac{(\text { abs. kontrol }- \text { abs. sampel) }}{\text { abs. kontrol }} \times 100 \%
\end{aligned}
$$

Hasil perhitungan dimasukkan ke dalam persamaan regresi $\mathrm{Y}=\mathrm{bX}+\mathrm{a}$ dengan konsentrasi ekstrak (ppm) sebagai absis (sumbu X) dan nilai \% inhibisi (antioksidan) sebagai ordinat (sumbu Y). Nilai IC50 dari perhitungan pada saat $\%$ inhibisi sebesar $50 \%$.

\section{HASIL DAN PEMBAHASAN}

Proses ekstraksi simplisia bunga telang ini menggunakan teknik maserasi yang merupakan teknik penyarian zat aktif dengan perendaman menggunakan pelarut polar atau non polar selama periode waktu tertentu sesuai dengan aturan dalam buku resmi kefarmasian. Penggunaan etanol $70 \%$ teknis sebagai pelarut dalam ekstraksi pada penelitian ini dikarenakan etanol $70 \%$ 
Tabel 1. Hasil Penentuan IC50 Lima Ekstrak Herba dan Vitamin C

\begin{tabular}{|c|c|c|c|c|c|}
\hline \multirow{2}{*}{ Ekstrak } & \multicolumn{3}{|c|}{ nilai $\mathrm{IC}_{50}(\mu \mathrm{g} / \mathrm{mL})$} & \multirow{2}{*}{$\begin{array}{c}\text { Rata-rata } \\
(\mu \mathrm{g} / \mathrm{mL}) \pm \mathrm{SD}\end{array}$} & \multirow{2}{*}{$\begin{array}{c}\text { Kategori antioksidar } \\
\text { (Reynertson,2007) }\end{array}$} \\
\hline & Rep 1 & Rep 2 & Rep 3 & & \\
\hline Bunga telang & 40,01 & 42,25 & 41,83 & $41,36 \pm 1,191$ & Sangat aktif \\
\hline Vitamin $\mathrm{C}$ & 5,78 & 6,44 & 6,543 & $6,25 \pm 0,414$ & Sangat aktif \\
\hline
\end{tabular}

mempunyai daya penetrasi yang baik pada sisi hidrofil dan lipofil, sehingga dapat menembus membran sel, masuk ke dalam sel dan berinteraksi dengan metabolit di dalam sel. Etanol $70 \%$ juga mampu menyari senyawasenyawa yang diperlukan untuk uji aktivitas bunga telang yaitu fenolik, flavanoid, alkaloid, terpenoid, dan steroid (Saifudin, 2014).

Aktivitas antioksidan ekstrak etanol bunga telang secara kuantitatif ditentukan dengan metode DPPH (1,1-diphenyl-2picrylhydrazyl), yaitu berdasarkan kemampuan ekstrak etanol bunga telang dalam mereduksi atau menangkap radikal DPPH. Kemampuan ekstrak etanol bunga telang dan pembanding vitamin $\mathrm{C}$ dapat dilihat dari berkurangnya intensitas warna ungu dari larutan DPPH yang telah ditambahkan dalam sampel dan pembanding. Berkurangnya intensitas warna larutan DPPH tersebut dapat menunjukkan bahwa terjadi reaksi antara atom hidrogen yang dilepas oleh bahan uji dengan molekul radikal DPPH sehingga terbentuk senyawa 1,1-difenil-2pikrilhidrazin yang berwarna kuning. Semakin besar konsentrasi bahan uji, warna kuning yang dihasilkan akan semakin kuat (Molyneux, 2004).

Pengurangan intensitas warna ungu larutan DPPH ini secara kuantitatif dapat dihitung dari berkurangnya absorbansi larutan tersebut. Semakin besar konsentrasi bahan uji maka absorbansi yang terbaca semakin kecil, yang berarti aktivitas bahan uji dalam menangkap radikal DPPH semakin besar. Absorbansi yang terukur merupakan absorbansi sisa DPPH yangtidak bereaksi dengan larutan uji (Molyneux, 2004).
Uji aktivitas antiradikal dengan metode DPPH dilakukan pada panjang gelombang 517,6 nm dengan waktu inkubasi 30 menit. Penentuan aktivitas antiradikal dilakukan melalui perhitungan inhibitory concentration (IC50). Nilai IC50 adalah konsentrasi ekstrak dan standar yang memberikan \% aktivitas antiradikal sebesar 50\% dibanding kontrol melalui suatu persamaan garis regresi linier antara kadar terhadap \% penangkapan radikal (Mailandari, 2012). Semakin besar nilai IC $_{50}$, semakin kecil aktivitas antioksidannya dan sebaliknya semakin kecil nilai $\mathrm{IC}_{50}$, semakin besar pula aktivitas antioksidannya.

Secara spesifik, suatu senyawa dikatakan sebagai antioksidan sangat kuat jika nilai $\mathrm{IC}_{50}$ kurang dari $50 \mu \mathrm{g} / \mathrm{ml}$, kuat untuk IC $_{50}$ bernilai $50-100 \mu \mathrm{g} / \mathrm{ml}$, sedang jika IC 50 bernilai 151$200 \mu \mathrm{g} / \mathrm{ml}$ (Molyneux, 2004). Hasil uji aktivitas antioksidan menunjukkan nilai $\mathrm{IC}_{50}$ ekstrak bunga telang sebesar 41,36 \pm $1,191 \mu \mathrm{g} / \mathrm{mL}$ dan nilai $\mathrm{IC}_{50}$ Vitamin $\mathrm{C}$ sebesar $6,25 \pm 0,414 \mu \mathrm{g} / \mathrm{mL}$ (Tabel 1). Hal ini menunjukkan bahwa sampel memiliki aktivitas antioksidan yang sangat kuat sedangkan untuk vitamin $\mathrm{C}$ memberikan nilai $\mathrm{IC}_{50}$ sebesar $6,25 \mu \mathrm{g} / \mathrm{ml}$ yang termasuk dalam kategori sangat kuat.

Hasil penelitian ekstrak bunga telang memiliki aktivitas antioksidan yang sangat kuat ini kemungkinan karena kandungan fenolik di dalamnya. Mekanisme antioksidan senyawa fenolik adalah berdasarkan reaksi reduksi oksidasi, di mana senyawa fenolik akan berperan sebagai agen pereduksi sehingga akan dapat mereduksi radikal bebas (reaktif) yang terbentuk menjadi spesies yang tidak reaktif lagi. Reaksi antara radikal DPPH dengan senyawa fenolik dalam bunga telang 

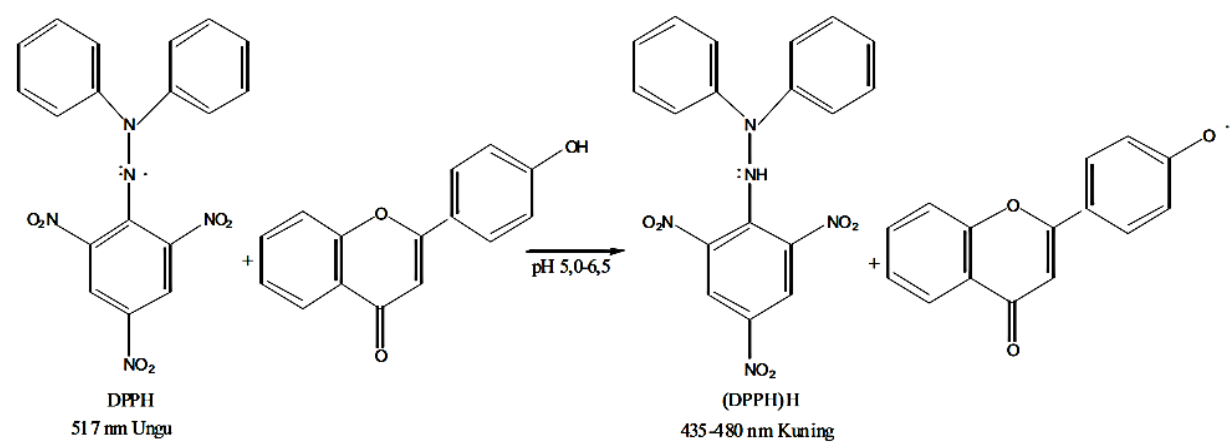

Gambar 1. Reaksi Antara Radikal DPPH dengan Senyawa Fenolik dalam Bunga Telang

sebagai senyawa penangkap radikal dapat dilihat pada gambar 1 .

Fenolik dalam ekstrak etanol bunga telang akan melepaskan $\mathrm{H}$ - yang merupakan salah satu radikal bebas. $\mathrm{H}$. akan berikatan dengan radikal DPPH membentuk senyawa baru yaitu difenil pikrilhidrazin yang stabil. Senyawa fenolik yang terkandung dalam ekstrak etanol bunga telang sebagai penangkap radikal bebas yang kehilangan $\mathrm{H}$. akan menjadi radikal baru yang relatif lebih stabil dan tidak berbahaya bagi tubuh karena adanya efek resonansi intiaromatik, sehingga radikal bebas tidak terbentuk dan dapat mencegah maupun memperbaiki kerusakan jaringan yang merupakan efek dari serangan radikal bebas. Senyawa fenolik memiliki bentuk gugus kimia heterogen yang mengandung gugus fenol (gugus hidroksil fungsional dalam cincin aromatik) dalam struktur dasarnya. Selain itu, senyawa fenolik mampu meningkatkan aktivitas enzim antioksidan dan menginduksi sintesis protein antioksidan (Walter and Marchesan, 2011).

Hasil penelitian ini berbeda dengan penelitian yang dilakukan oleh Anisa (2019) yang menyebutkan ekstrak etanol bunga telang tidak poten sebagai antioksidan. Hal ini kemungkinan disebabkan karena perbedaan ketinggian tempat tumbuh dan juga perbedaan konsentrasi etanol yang digunakan sebagai cairan penyari. Berdasarkan penelitian Sholekah (2017) menyebutkan bahwa kandungan fitokimia hasil dari metabolit sekunder seperti flavonoid dan beta karoten dari suatu tanaman akan berbeda pada setiap wilayah dipengaruhi oleh faktor lingkungan di antaranya cahaya, suhu, $\mathrm{pH}$, ketinggian tempat, serta temperatur.

Selain itu hal lain yang berpengaruh terhadap total flavonoid dan aktivitas antioksidan adalah konsentrasi etanol yang digunakan. Pada penelitian Anisa (2019), pelarut yang digunakan adalah etanol 96\%, pada penelitian ini pelarut yang digunakan adalah etanol $70 \%$. Penelitian Suhendra, dkk (2019) menyebutkan bahwa konsentrasi pelarut etanol berpengaruh sangat nyata terhadap rendemen, total fenol, total flavono id dan aktivitas penghambat radikal DPPH ekstrak, dengan kandungan tertinggi diperoleh pada etanol konsentrasi $70 \%$.

\section{KESIMPULAN}

Nilai $\mathrm{IC}_{50}$ ekstrak bunga telang (Clitoria ternatea L) sebesar $41,36 \pm 1,191 \mu \mathrm{g} / \mathrm{mL}$, termasuk kategori sangat poten sebagai antioksidan.

\section{Daftar Pustaka}

Andriani, D. and Murtisiwi, L., 2018. Penetapan Kadar Fenolik Total Ekstrak Etanol Bunga Telang (Clitoria ternatea L.) dengan Spektrofotometri UV Vis. Cendekia Journal of Pharmacy, 2 (1): 32-38. 
Anisa, N., 2019. Potensi Ekstrak Bunga Telang (Clitoria Ternatea) Sebagai Antioksidan dan Inhibitor Tirosinase, Skripsi, Institut Pertanian Bogor, Bogor.

Apak, R., Gorinstein, S., Böhm, V, Schaich, K.M., Özyürek, M., and Güçlï, K., 2013. Methods of Measurement and Evaluation of Natural Antioxidant Capacity/ Activity (IUPAC Technical Report). Pure and Applied Chemistry, Vol. 85 (5): 957-998.

Departemen Kesehatan RI. 2008. Farmakope Herbal Indonesia Edisi I. Jakarta, 174.

Dutta, S. \& Ray, S., 2014 Evaluation of Antioxidant Potentials of Leaf Aqueous and Methanolic Extracts of Calophyllum inophyllum in Relation to Total Phenol and Flavonoid Contents. International Journal of Pharma and Bio Sciences, 5(3), 441-450.

Gupta, G.K., Jagbir, C., and Manisha, B., 2010. Clitoria ternatea (L.): Old and new aspects. Journal of Pharmacy Research, 3(11), 2610-2614.

Kazuma, K., Noda, K., and Suzuki, M., 2013. Flavonoid composition related to petal color in different lines of Clitoria ternatea. Phytochemistry, 64 (1133-1139).

Kogawa K, Kazuma K, Kato N, Noda N and Suzuki M., 2006. Biosynthesis of malonylated flavonoid glycosides on the basis of malonyltransferase activity in the petals of Clitoria ternatea. Journal of Plant Physiology, 2(6), 374-379.

Mailandari, M., 2012. Uji aktivitas antioksidan ekstrak daun Garcinia kydia roxb. dengan metode DPPH dan identifikasi senyawa kimia fraksi yang aktif. Skripsi. Universitas Indonesia.

Molyneux, P., 2004. The use of the stable free radikal diphenyl picrylhydrazyl (DPPH) for estimating antioxidant activity. Journal Science of Technology, 26 (2): 211-219.

Phaniendra, A., and Jestadi, D,B., 2015. Free Radicals: Properties , Sources, Targets , and Their Implication in Various Diseases. Indian Journal of Clinical Biochemistry, Vol. 30 (1): $11-26$

Purba, E,C., 2020. Kembang Telang (Clitoria ternatea L.): Pemanfaatan dan Bioaktivitas. EduMatSains, 4 (2), 111-124

Saifudin, A., 2014. Senyawa Alam Metabolit Sekunder: Teori, Konsep, dan Teknik Pemurnian. Yogyakarta: Depublish Publisher.

Sholekah, F., 2017. Perbedaan Ketinggian Tempat Terhadap Kandungan Flavonoid Dan Beta Karoten Buah Karika (Carica Pubescens) Daerah Dieng Wonosobo. Prosiding, Seminar Nasional Pendidikan Biologi dan Biologi.

Suhendra, C.P., Widarta, I.W.R., and Wiadnyani, A.A.I.S., 2019. Pengaruh Konsentrasi Etanol Terhadap Aktivitas Antioksidan Ekstrak Rimpang Ilalang (Imperata Cylindrica (L) Beauv.) Pada Ekstraksi Menggunakan Gelombang Ultrasonik. Jurnal Ilmu dan Teknologi Pangan, Vol. 8, No.1, 27-35.

Susantiningsih, T., 2015. Obesitas dan Stres Oksidatif. Jurnal Kedokteran Unila, Vol 5, No. 9

Terahara, N., Toki, K., Saito, N., Honda, T., Matsui, T., and Osajima, Y., 1998. Eight new anthocyanins, ternatins $\mathrm{C} 1-\mathrm{C} 5$ and D3 and preternatins $\mathrm{A} 3$ and $\mathrm{C} 4$ from young Clitoria ternatea flowers. J Nat Prod, 61(11), 1361-1367.

Walter, M., and Marchesan, E.. 2011. Phenolic Compounds and Antioxidant Activity of Rice. Brazilian Archives of Biology and Technology, Vol. 54 (2): 371-77. 
Werdhasari, A., 2014. Peran Antioksidan Bagi Kesehatan. Jurnal Biotek Medisiana Indonesia, Vol. 3, No. 2, 59-68

Widhihastuti, E., 2011. Pengukuran Aktivitas Antioksidan dengan Metode DPPH serta Korelasinya dengan Kadar Fenolik Pada Lima Jenis Herba Bahan Obat Alam Indonesia. Skripsi. Universitas Muhammadiyah Surakarta, Surakarta. 